\title{
NEW PATHS IN AUSTRIAN MACROECONOMICS
}

\author{
WILLIAM BARNETT II* \\ WALTER E. BLOCK**
}

Fecha de recepción: 7 de enero de 2012.

Fecha de aceptación: 19 de diciembre de 2012.

Resumen: Este artículo desarrolla una versión modificada de la teoría austriaca del ciclo económico en la que el papel protagonista lo juegan las expectativas de beneficio de los empresarios (más que la reducción de la preferencia temporal de los agentes económicos) y la asunción de proyectos empresariales más arriesgado, como principal detonante de las malas inversiones.

Palabras clave: Riesgo, Fondos prestables, Activos financieros, Teoría austriaca del ciclo económico.

\section{Clasificación JEL: E32.}

Abstract: This paper makes four points. First, interest rates are not prices; rather they are metrics. Second, there are no markets for «loanable funds» in reality, so attempts to use «the» market for loanable funds either to explain savinginduced growth (or growth induced in other ways) are misleading. Rather, the appropriate concept is markets for financial assets. Third, the primary and most important source of growth is not households' low or reduced time preferences, but entrepreneurs high or increased profit expectations. Fourth, financial institutions may respond, in part, to a rise in the monetary base by

* Professor of Economics and Chase Bank Distinguished Professor of International Business. Joseph A. Butt, S.J., College of Business. Loyola University New Orleans. 6363 St. Charles Ave. New Orleans, LA 70118 (504) 864-7950 wbarnett@loyno.edu. http://www.business.loyno.edu/faculty/wbarnett.

** Harold E. Wirth Eminent Scholar Endowed Chair and Professor of Economics.

Joseph A. Butt, S.J. College of Business. Loyola University New Orleans. 6363 St. Charles Avenue, Box 15, Miller Hall 318. New Orleans, LA 70118. Tel: (504) 864-7934, fax: (504) 864-7970. wblock@loyno.edu. http:/ / www.walterblock.com/.

Procesos de Mercado: Revista Europea de Economía Política Vol. X, n.․ㅜ 1, Primavera 2013, pp. 91 a 114 
accepting a higher default risk of their assets; i.e., by making riskier loans and buying riskier (financial) assets, in order to maintain nominal interest rates and net interest margins.

Key words: Risk, Loanable funds, Financial assets, Austrian business cycle theory.

JEL Classification: E32.

I

INTRODUCTION

In this paper we contend that the standard, modern, Austrian Business Cycle Theory (hereinafter, ABCT) is in reality a somewhat special theory. ${ }^{1}$ We extend the standard, modern, Austrian Business Cycle Theory (ABCT), and do so with a modified exposition. ABCT is extended to consider the cases in which: 1) sustainable, natural growth results from an increase in investment consequent on rises in profit expectations rather than an increase in saving resulting from a decline in time preferences; and, 2) an unsustainable, artificial boom is initiated by malinvestment/ forced-saving generated by a reduction in risk ${ }^{2}$ standards; i.e., by riskier credit, rather than by reductions in interest rates consequent on increases in fiat-money/credit; i.e., monetary/credit inflation. The exposition is modified such that it focuses on markets for financial assets (FA) in addition to the more typical loanable funds (LF).

In section II we offer a brief overview of the U.S. financial system and the Austrian Business Cycle Theory (ABCT). Section III is devoted to our introduction of risk and its more explicit incorporation into ABCT. The burden of section IV is to compare

1 Throughout we limit our analysis to the modern U.S. However, the extension to different institutional environments is straightforward, provided they are based on fiat money, a central bank, and a number of commercial banks, as is the case in the U.S.

2 Throughout we use «risk» to refer to both Knightian or «true» uncertainty and also to probabilistic uncertainty. 
saving versus investment induced growth. We attempt in section $\mathrm{V}$ to analyze increased risk $\mathrm{v}$. lower nominal rates of interest. Then, in section VI we attempt to extend ABCT into a more general theory, including both risk and this alternative source of growth, stemming from the entrepreneur/producer, not the household/ consumer-saver. We compare, in section VII, the standard $\mathrm{ABCT}$ with our own extension of it, and conclude in section VIII.

\section{II}

\section{BRIEF OVERVIEW OF THE U.S. FINANCIAL SYSTEM}

The modern, allegedly-free U.S. financial system consists, inter alia, of; 1) fiat money; to wit: Federal Reserve (Bank) Notes (FRNs) and electronic demand-deposits; 2) the Federal Reserve System (FRS) - a central banking system; and, 3) a number of highly regulated commercial banks. The primary way that the fiat-money stock is increased is through purchases of financial assets (FAs), usually governmental debt, by the FRS, ${ }^{3}$ which purchases they pay for by increasing directly or indirectly the excess reserves in the banking system. ${ }^{4}$ In normal times, the commercial banks use these excess reserves to make loans; i.e., acquire notes, and also to acquire other FAs. 5, 6,7 In so doing, they

3 Actually, such purchases are usually made by the Federal Reserve Bank of New York (FRBNY), one of the 12 Federal Reserve Banks (FRBs) that, along with the Board of Governors, comprise the FRS, as directed by the Federal Open Market Committee (FOMC), the main policy committee of the FRS.

${ }^{4}$ Such purchases of FAs drive up their prices and down their yields. Of course, if investors think that such money creation/asset purchases will generate sufficient price inflation or default risk, the opposite results could obtain.

5 As this paper is being written in late 2011, times are not normal. One may reasonably say that historically in normal times excess reserves have constituted approximately $1 \%$ of total reserves whereas presently they comprise approximately $95 \%$.

6 Such investments also lower the interest rates that banks can charge on loans and bid up the price and down the yields on the other FAs in which they invest the excess reserves; however, different results may obtain, see fn.3, supra.

7 Mises $(1998,430)$ refers to: «circulation credit, i.e., credit granted out of the issue of fiduciary media.» That is, credit generated by creating and lending new fiat money, whether in the form of banknotes or deposits. 
increase the amount of demand deposits in the banking system; i.e., they increase the supply-of-credit/stock of money. ${ }^{8}$

Austrian Business Cycle Theory (ABCT) maintains that because of substitution effects, i.e., portfolio adjustments, the prices of other assets both financial and real, will also increase and their yields also decrease, though neither simultaneously nor by the same amounts or rates. These various declines in yields induce systematic but unsustainable misallocations of resources. A crisis occurs when real yields increase, which eventually they must, either because peoples' expectations regarding inflation are ignited ${ }^{9}$ or because the money creation is brought to a halt because of a lack of will on the part of the central banking authorities. Then, the misallocations are exposed as exactly that, bringing to an end the false boom. The mistakes of the boom must be liquidated in the subsequent bust. This does not necessarily, although it may sometimes, mean physical destruction. Rather, the usual method is to destroy a part of the monetary value of the misallocated resources to the point at which it is profitable to reintegrate them into the structure of production. We do not at all disagree with this traditional

8 The traditional term is of the nature: "an increase in the stock of fiat money.» That, however, is unsatisfactory. In modern societies that have fractional-reservebanking systems, the fiat-money stock is increased by central banks lending it into existence in the process of purchasing assets with newly created paper or electronic fiat money. It could, of course, instead, be spent into existence by a central government in the process of financing a budget deficit; i.e., it could be spent, rather than lent, into existence. There is a major and critically important difference between the effects of lending and spending new money into existence. A spending-inflation of the monetary stock causes, ceteris paribus, a price inflation concentrated, at least initially, in the goods sector, not in the financial assets sector. That is, there is no reason to expect it to affect interest rates systematically, and thus the structure of production is not systematically and unsustainably distorted. Thus there is no «false» boom, subsequent crisis, and bust. That is, spending new money into existence doesn't cause an $\mathrm{ABC}$ because credit markets and conditions are not necessarily affected. Of course, that is not true when new money is lent into existence. Although credit conditions are not eased when new money is spent into existence and thus there is no initiation of an $\mathrm{ABC}$, only a «pure price inflation,» when credit conditions are artificially eased, usually because new money is lent into existence, an ABC is initiated.

9 This can be done through expectations of continually rising prices. See on this Hayek, 1972. 
$\mathrm{ABCT}$ analysis; however, we do think it incomplete. Therefore, we extend it in several areas so as to make it a more general theory.

\section{III}

\section{OVERVIEW OF THE U.S. FINANCIAL SYSTEM AND ABCT}

Consider the pedagogical device known as the loanable funds model used to elucidate ABCT by, e.g., Garrison (2001,37). This model is depicted in figure 1, wherein "the» interest rate is measured on the vertical axis and «the» quantity of loanable funds, along the horizontal, and $\mathrm{D}_{\mathrm{LF}}$ and $\mathrm{S}_{\mathrm{LF}}$ represent, respectively, «the» demand for and «the» supply of loanable funds. ${ }^{10}$

FIGURE 1

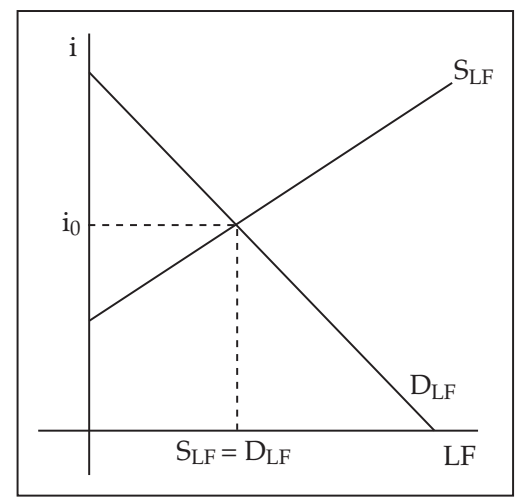

In $\mathrm{ABCT}$ this figure is used to illustrate the difference between sustainable saving-induced growth (figure 2A) and a monetary / credit expansion-induced unsustainable boom (figure 2B).

The story told by figure $2 \mathrm{~A}$ is that of an increase in the $\mathrm{S}_{\mathrm{LF}}$ as a result of a change in peoples' preferences. People are now wi-

10 We place «scare quotes» around these words and phrases because, frankly, we are «scared» that they are too aggregated for Austrian theory, resulting in incomplete and sometimes misleading analysis. 
FigURES 2A AND 2B

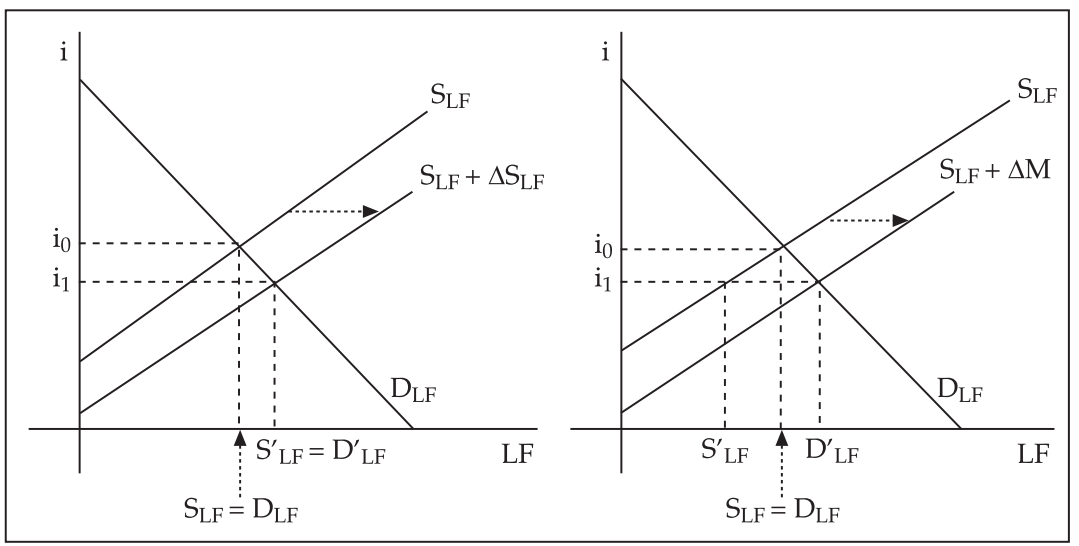

lling and able to supply more loanable funds at various rates of interest. Their preferences to lend more may have increased for a number of reasons; e.g., lessened time preferences or increases in wealth. In this case, at the preexisting interest rate a surplus of loanable funds is created resulting in a decline in the interest rate and an increase in the quantity demanded of loanable funds. The result is a rise in the value of loanable funds exchanged that is in keeping with these freely chosen actions and therefore reflects peoples' true preferences. Thus, the increased volume of LF exchanged is sustainable.

Figure $2 \mathrm{~B}$ also relates a scenario in which the $\mathrm{S}_{\mathrm{LF}}$ increases. However, despite surface appearances, this is a very different situation from that depicted in $2 \mathrm{~A}$. In this case individuals have not chosen to lend more at various interest rates; rather, banks have increased the $S_{\mathrm{LF}}$ by lending out newly created money. In this case, also, interest rates decline because of a surplus of LF at the preexisting interest rate. The adjustment to this disequilibrium involves, inter alia, that the quantity demanded of LF increases, and the total value of loanable funds exchanged climbs. But in this case, the results are not in keeping with individuals' true preferences, and thus are not sustainable.

The analysis, supra, in terms of LF would be more in keeping with the normal course of events were it instead done in terms 
of FAs. ${ }^{11,12}$ This is because, the usual economic practice and pedagogy to the contrary notwithstanding, there really is no such thing as a market for loanable funds. In markets in monetary economies, non-monetary goods exchange for money. In that process of exchange a price is set. ${ }^{13}$ However, interest rates, again, the usual economic pedagogy to the contrary notwithstanding, are not prices. ${ }^{14}$ Interest rates arise only in the course of credit transactions. ${ }^{15}$ Such transactions consist of the exchange of a promise to pay an amount or amounts of money at some time(s) in the future for an amount of actual money in the present. ${ }^{16}$ The promise to pay is, usually, legally binding on the borrower/ promisor and usually evidenced in writing; e.g., a note or bond. Thus, in a market for a financial asset; e.g., bonds, the bonds exchange for a price; i.e., an amount of money. Alternatively, consider a soi-disant market for loanable funds. What is the non-money good that is exchanged for the loanable funds; i.e., for the money?

11 We assume throughout that in considering the effects of changes in the supply and / or demand for LFs and / or FAs, what is of interest is the monetary value of new loans/FAs; i.e., we exclude preexisting loans/FAs.

12 The dimensions/units on both of the axes of LF and FA figures differ. The vertical axis of all LF figures measures nominal interest rates whereas that of FA figures measures money prices. The horizontal axis of all LF figures measures amounts of money, whereas that of FA figures measures quantities of FA; e.g., for a specific heterogeneous FA, say a \$1,000 T-bill from a particular borrower, the horizontal axis would measure the number of such homogeneous T-bills.

13 As Mises $(1998,218)$ states: «The prices are not measured in money; they consist in money.»

14 Interest rates are metrics used to compare FAs of different (face) values, different terms to maturity, different default risks, etc., much as one might use dollars of expense per passenger mile to compare airplanes of different sizes, different vintages, etc. However, both FAs and planes are actually sold for prices; i.e., amounts of money (Mises, 1998, 218). There are no actual markets for loanable funds as such and therefore no prices for them; moreover, even if there were such markets the prices could not be interest rates as they are metrics, not amounts of money; i.e., not prices. Moreover, a LF model can only deal with liabilities, not equity. That is, loans are debts, whereas FA may be either debts or equity, and thus can accommodate issuances of stocks as well as debt instruments.

15 The first mentioned author of this paper fully supports this contention. The second mentioned author demurs, and would add to this claim, with which he of course agrees, the price spread between the various stages of production, as depicted in Rothbard (2004, ch. 6).

16 Interest rates are metrics that are used to compare loans that vary in terms of principal, maturity, etc. 
And, what is the price? It cannot be an interest rate. Moreover, in some expositions of the LF model, the $S_{L F}$ and the $D_{L F}$ are replaced by saving and investment, respectively, with the interest rate in those cases treated not as the price of loanable funds, but rather as the price(s)? of saving and investment. This is truly problematical. ${ }^{17} \mathrm{So}$ as figures $2 \mathrm{~A}$ and $2 \mathrm{~B}$ illustrate saving induced growth and a monetary/credit expansion induced unsustainable boom in terms of LF analysis, so figures $3 \mathrm{~A}$ and $3 \mathrm{~B}$ illustrate the same concepts, respectively, in terms of FA analysis.

Figures 3A AND 3B

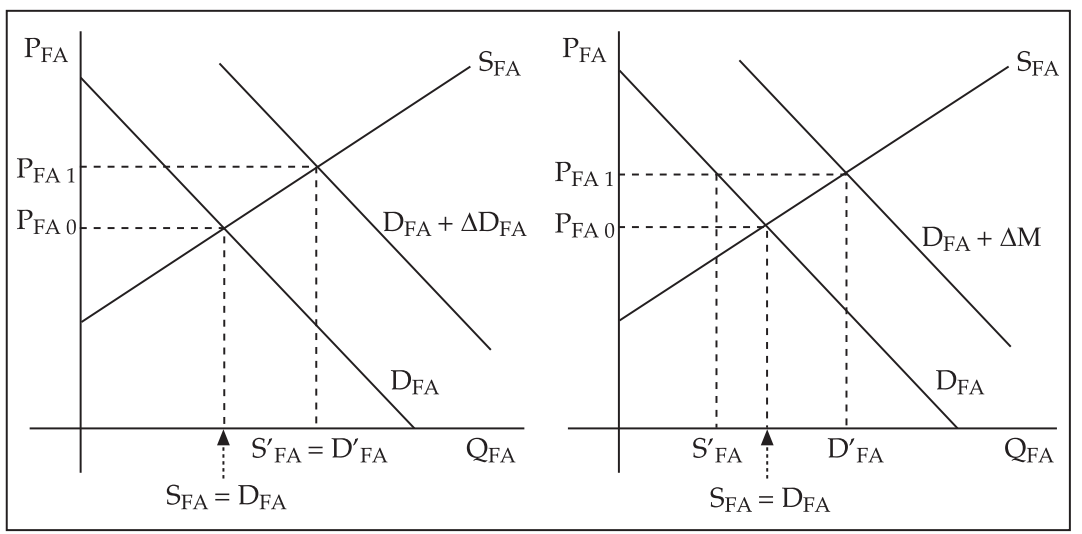

IV

\section{SAVING VERSUS INVESTMENT INDUCED GROWTH}

The comparison of saving induced growth with a monetary/credit expansion induced unsustainable boom, regardless of whether exposited using a LF model or a FA model, is interesting and provides some insight. However, if we are to judge by bond prices

17 Properly understood, saving and investment are identical (Barnett and Block, 2007). The implication of our LF figures and analysis is that at any interest rate save «the» market clearing rate, either saving exceeds investment or investment exceeds saving. 
or yields, it appears that growth is not usually saving induced, but rather investment induced. ${ }^{18}$ In contradistinction to the "circular-flow» models of the economy as per the standard text books, production precedes consumption. Without production, there can be no consumption; however, without consumption, production can still exist. Entrepreneurs initiate; they and they alone ${ }^{19}$ decide what to produce, in what quantities, and how to produce it. In order to do so, they have to be able to gain control of sufficient resources for their purposes. To the extent that they produce new capital goods; ${ }^{20}$ i.e., invest, to exactly that extent does saving occur. Thus, when entrepreneurs perceive opportunities to invest that they judge will prove profitable, they go about acquiring the necessary resources and undertaking the relevant projects. That is, the motivation behind growth is an increase in profit expectations (that results in a rise in investment), not a decrease in time preferences (that engenders a boost in saving). ${ }^{21}$ In figures $4 \mathrm{~A}$ and $4 \mathrm{~B}$ we compare saving induced growth with investment induced growth using the LF model. Then, in figures $5 \mathrm{~A}$ and $5 \mathrm{~B}$, we compare them using the FA model.

Compare the two cases using the LF model. ${ }^{22}$ Assume that the post-change increase in the market clearing quantity of LF is the same in both cases. That is, whether it was because of a saving induced increase in the supply of LF or because of an investment induced increase in the demand for LF, the shift

18 This is not to buy into Keynes' (1936) «animal spirits» version of investment; however, it is not incompatible with Schumpeter's (1934) innovation driven model. In any case, if one does accept Keynes' argument, there is no a priori reason to think that consumers would not also be affected by such «animal spirits.»

19 Syndicalists, or at least some of them, too, must act as entrepreneurs.

20 For the purposes of this paper we ignore the investment/saving element in the production of consumers' durables, and dodge the issue of residential construction.

21 Suppose that time preferences fell, exogenously of course, but entrepreneurs saw no additional profitable opportunities apart from that fact. According to the thesis of this paper, would any additional investment take place? Yes. If time preferences fell, the interest rate would decrease, and, ceteris paribus, there would have to be more profit opportunities if nothing else changed.

22 We understand that there are multiple «markets» for LF and multiple markets for FA. However, for ease of grammatical exposition we use the singular not the plural. 
Figures 4A AND 4B

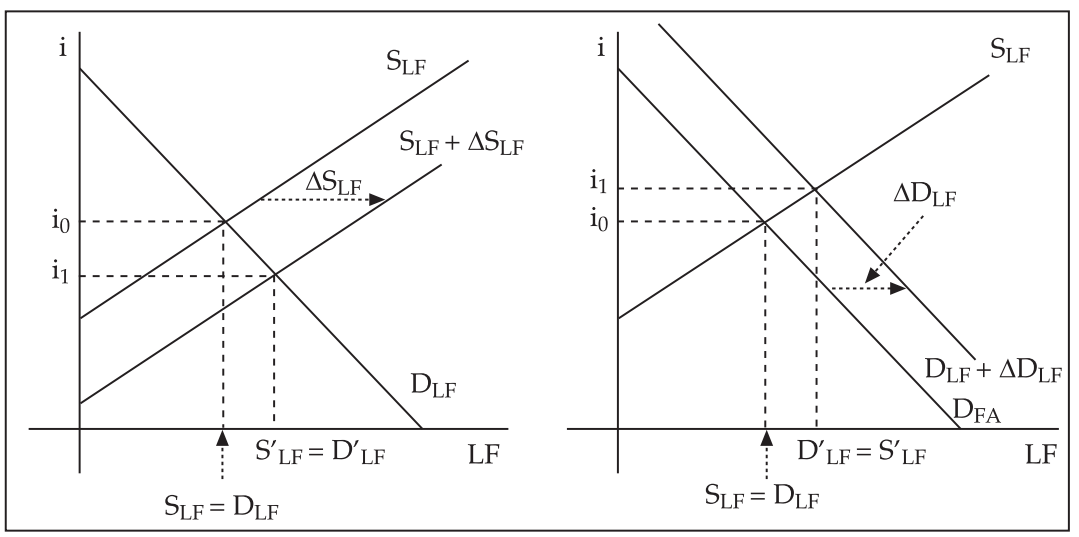

Figures 5A AND 5B
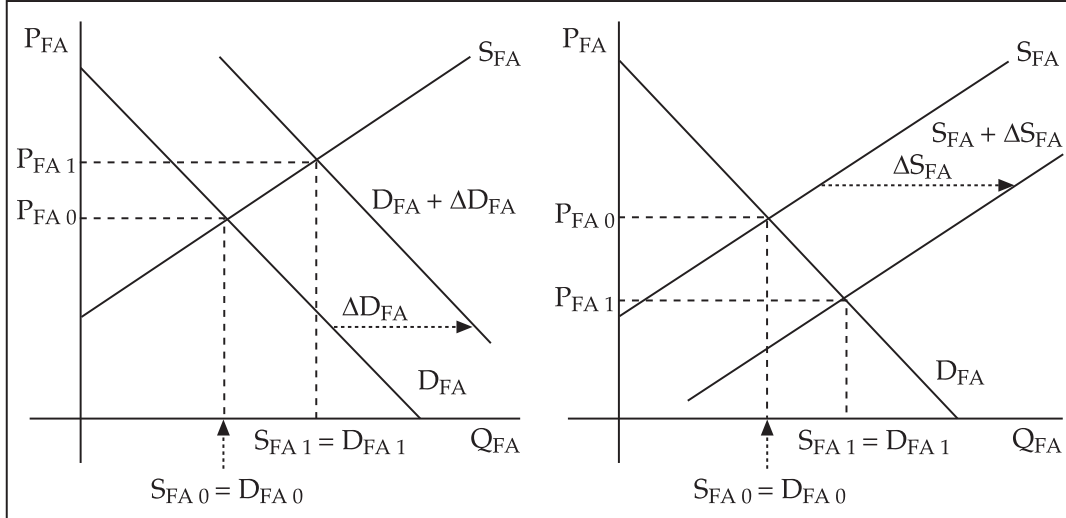

in quantity is identical. However, there is a critical difference between the two scenarios in terms of the post change market clearing interest rates. In the former case, it decreases, whereas in the latter it increases. This is not an inconsequential matter. If we then compare the two cases using the FA model (5A and $5 B)$, we see analogous results.

Again, assuming an equal increase in the post change market clearing quantity of FA, in the case of an increase in the demand for FAs because of an increase in saving, the price of FA increases, 
whereas when the supply of FA rises because of an increase in investment, the price of FA decreases. ${ }^{23}$

\section{$\mathrm{V}$ \\ INCREASED RISK V. LOWER NOMINAL RATES OF INTEREST}

At this point, we consider the case when lenders chase yield; i.e., lenders are willing to lend to riskier borrowers. ${ }^{24,}{ }^{25} \mathrm{We}$ do so, first, in terms of LF analysis (figures 6A \& 6B) and then in terms of FA analysis (figures 7A \& 7B). In terms of LF analysis, at relevant interest rates they are willing to lend more than they had been previously. And, in terms of FA analysis, at relevant prices they are willing to buy riskier securities.

\section{FIGURES 6A AND 6B}

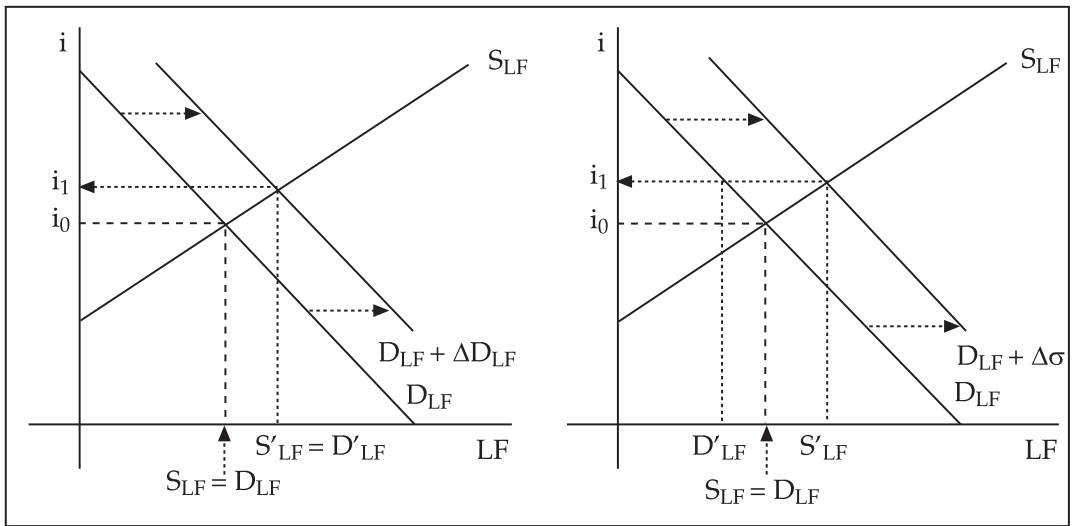

23 Of course, these results are consistent with those of the LF model.

24 The risk referred to here is that of default.

25 It is important to note that as we are considering markets, not individuals or firms, it is probably safe to assume that not all lenders are willing to accept greater risk, and that even those who are, are not all willing to accept the same greater degree of risk. This is thus an average concept, similar to the claim that men on average are taller than women. 
FIGURES 7A AND 7B

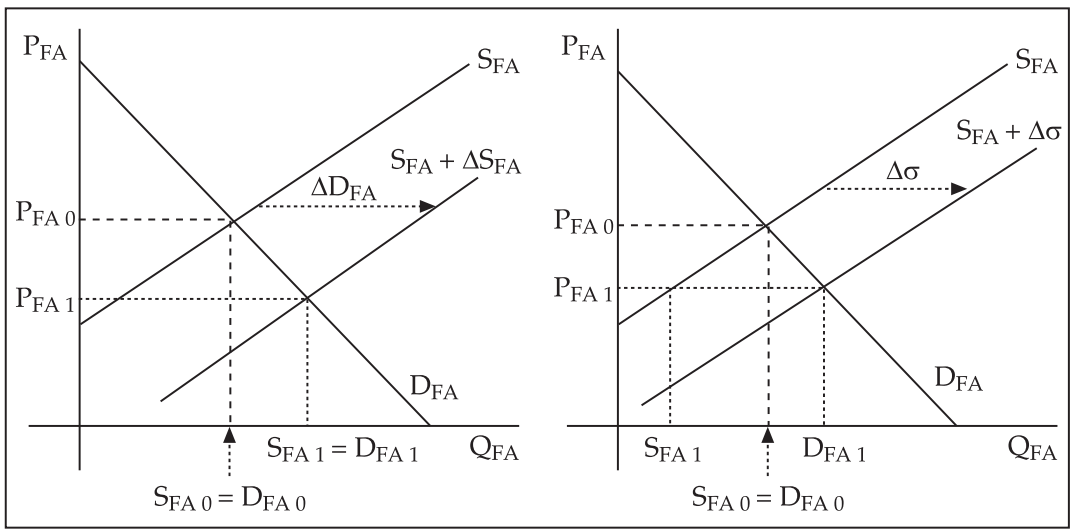

As always, demand functions have more than one argument. Similarly for supply functions. Thus, when depicting them in a two-dimensional space, all variables except those indicated on the axes necessarily are held constant along each demand and each supply curve. ${ }^{26}$ Of course, changes in their values are depicted as shifts in either the demand or the supply curve, or both. Moreover, it is especially important to remember that demand and supply curves are not independent, save in the ludicrous soi-disant case of perfect competition. ${ }^{27}$ And, just as

26 In fact, demand and supply analysis is a metaphor used as a pedagogical device by economists, and has no independent existence in reality. Thus, when we hold that a decline in price caused by an increase in supply will, ceteris paribus, result in an increase in the quantity demanded and thus an increase in the quantity sold, the very proposition itself is impossible. That is, it is impossible for the price to decline solum. In fact, the assumption of ceteris paribus means that the analyst is assuming that any changes in other factors are of sufficiently small magnitudes that for the purpose of his analysis they may be ignored. See on this Barnett and Block, 2010.

27 The standard microeconomic theory of profit maximization requires that $\mathrm{MR}$ $=\mathrm{MC}$, where $\mathrm{MR}=\mathrm{P}+\mathrm{Q}(d \mathrm{P} / d \mathrm{Q})$. Therefore, $\mathrm{P}+\mathrm{Q}(d \mathrm{P} / d \mathrm{Q})=\mathrm{MC}$. Thus $\mathrm{P}=\mathrm{MC}$ only if $d \mathrm{p} / d \mathrm{Q}=0$; i.e., if the slope of the demand curve is zero. In other words, the profit maximizing quantity for any price is that at which $\mathrm{P}=\mathrm{MC}$. As neoclassical theory assumes that there is only one MC for every quantity (pace Leibenstein (1966) and his theory of X-efficiency) in perfect competition where the demand curve of the firm has zero slope, there is a single price (quantity) that will be asked (offered) by a profit maximizing firm at each quantity(price); i.e., the supply curve is defined and 
price is an argument in both supply and demand functions, so also is default risk when the relevant good, whether in whole or in part, is credit. Thus, in the case under consideration, the risk of default is held constant along each LF demand and supply curve. Lenders' willingness to take on more risk of default causes an outward shift of the LF demand curve; i.e., demand for LF increases. And, it also causes a shift in the LF supply curve - in this case an upward shift; i.e., the supply of LF decreases. ${ }^{28}$ In consequence, the interest rate increases. Whether because of this decrease in risk aversion, the monetary value of loan transactions increases, decreases, or is unchanged depends on the relative magnitudes of the changes in the demand for, and supply of, LF. Alternatively, lenders' willingness to take on more risk of default causes an outward shift of the FA supply curve; i.e., the supply of FA increases. And, it also causes a shift in the FA demand curve - in this case a downward shift; i.e., the demand for FA decreases. In consequence, the prices of FAs decrease. Whether because of this decrease in risk aversion, the monetary value of loan transactions increases, decreases, or is unchanged depends on the relative magnitudes of the changes in the demand for, and supply of, FA. ${ }^{29}$

\footnotetext{
determined. However, whenever $d \mathrm{P} / d \mathrm{Q} \neq 0$; whenever the a profit maximizing firm's demand curve slopes downward, there is no unique price that maximizes profit for any specific quantity; rather the profit maximizing price depends not only on the specific MC for an given quantity, but also on the elasticity of demand at that quantity. That is the profit maximizing equation may be written as: $\mathrm{P}+\mathrm{MC}(1 /(1+(1 / \varepsilon))$, where is the elasticity of demand. Therefore, when a firm's demand curve slopes - when it must lower price to sell a larger quantity, no supply curve exists; rather, only individual supply points exist.

${ }^{28}$ Here is a possible objection to the foregoing. The text makes it sound as if risk affects both supply and demand, both borrowers and lenders. But default risk applies only? mainly? to lenders, not to borrowers. Lenders and only lenders risk losing their money. The only thing borrowers risk losing is their credit rating. Debtors' prison is no longer on the table. Here is our response to this possible objection: changes in default risk $(\sigma)$ affects both the supply and demand curves for LFs. On the one hand, if $\sigma$ increases ceteris paribus, the lender wants and can insist upon a higher interest rate for any given quantity of LFs supplied; on the other hand, the lender can cause the LFs demand curve to shift outward by accepting higher-risk borrowers.

${ }^{29}$ We do not illustrate the effect of an increase in default risk on the supply of $\mathrm{LF} /$ demand for FA curves in any of our figures.
} 
Figure 6A depicts an increase in the demand for LF as a result of an increased desire of entrepreneurs to invest; e.g., because of new technology, with risk assumed constant. Alternatively, figure $6 \mathrm{~B}$ illustrates an increase in the demand for LF as a result of a willingness of lenders to take on additional risk.

Figure 7A depicts an increase in the supply of FA as a result of an increased desire of entrepreneurs to invest. Alternatively, figure $7 \mathrm{~B}$ illustrates an increase in the supply of FA as a result of a willingness of lenders to take on additional risk. That is, higher risk securities become part of the supply of FA as lenders will now buy them whereas before they would not. ${ }^{30}$

The issue then arises as to whether the increased supply of, and decreased demand for, FA, and the consequences thereof; to wit, lower prices/higher yields and any change in value of FA sold, are true market phenomena or, rather, the result of something very different; to wit: government intervention. If the former, then the uses of the increased finance do not lead to misallocations of resources beyond the usual level resulting from the always imperfect judgment of borrowers and lenders; i.e., there is nothing systematic about them. If the latter, however, then systematic misallocations of resources must indeed result. It is customary, in $\mathrm{ABCT}$, to refer to these latter effects in terms of malinvestment and / or forced saving. However, depending on how the financial markets react in terms of the allocation of funds between consumers and producers, and among consumers, it is possible that we will have malproduction of consumers' goods, in contradistinction to malinvestment. ${ }^{31}$ More probable is that what actually occurs is a combination of malinvestment and malproduction of consumers' goods. It is also possible that forced dissaving ${ }^{32}$ occurs instead of forced saving.

30 Of course, it is not an all or nothing situation regarding riskier securities.

31 The reason we use the inelegant term «malproduction of consumers' goods» instead of the more fluid "malconsumption» is that economists use «consumption» ambiguously - as an act of consuming, as an act of spending on a consumers' good, and also as an act of production of a consumers' good.

32 Forced saving means a forced increase in saving beyond what it otherwise would have been, so forced dissaving here means a forced reduction in saving below what it otherwise would have been. 
VI

TOWARD A MORE GENERAL ABCT

We now use Austrian theory to explain business cycles from the perspective described, above. We no longer need resort to the driving force being the actions of consumers motivated by a decrease in their time preferences [sic]. ${ }^{33}$ Using the FA model, we can now look at these matters from an alternative, or additional perspective: entrepreneurs increase the supply of FA in order to finance newly perceived opportunities based on innovations of various types. To the extent that lenders are favorably impressed by the entrepreneurs' plans, they will purchase the new FA. That is, in response to the increased supply of FAs, the quantity demanded thereof will increase. This will result in lower prices/ higher yields for the FAs, the extent depending upon the elasticity of demand for them. The new projects so financed will use resources diverted from other uses. Traditional ABCT maintains that these resources will be diverted from the production of consumers' goods and lower order capital goods to the production of the higher order capital goods that constitute the new projects undertaken. However, given our new model, this is not at all certain. In fact, these resources may be diverted from idleness. ${ }^{34}$ So, shut-in oil and gas wells may be brought back on line, closed mines, factories, warehouses, and retail space-may be reopened, empty office space may be filled, rolling stock may be used more intensively, factories may run additional shifts, the maintenance of machines may be postponed, inventories of raw materials and parts may be drawn, etc. Perhaps most important, «idle» labor

33 Praxeologically, as there can be no such thing as a rate of time preference, neither can be any such thing as a decrease (or increase) in (that non-existent rate of) time preference. This is not to deny that from the thymological perspective there can be such an increase (or decrease). In like manner, a person can prefer a red to a blue shirt. That is a matter of praxeology. But, there cannot be any rate at which this preference takes place.

34 Idleness is here used in the engineering sense. In the economic sense, each and every all resource is at all times being put to the use deemed most valuable by its owner. However, in the engineering sense, a machine that is not being used is (physically) idle. And, of course, leisure is the human analog of non-human idleness. 
may be employed; e.g., retired workers, students, homemakers, and people previously «unemployable» may take jobs.

Thus, contrary to traditional $\mathrm{ABCT}$, in which consumers are the driving force behind growth via reduced time preferences and increased saving, we postulate the entrepreneur as the driving force via increased profit expectations and increased investment. This would seem to be more in keeping with the standard $\mathrm{AE}$ conception of the entrepreneurs as the key actors in an economy. It is not that we wish to jettison mainstream $A B C T$. We do not deny its validity. However, we offer this new model as a supplement, if not a complement, to the lowered time preference perspective. Just because one is correct does not render the other invalid.

Alternatively, the source of the increased supply of FA might be consumers. Note that this is a polar opposite to the case of consumers' decreased time preferences causing an increase in demand for FA. Consumers might increase their demand for FA if their time preferences decrease and they wish to save more. Alternatively, if their time preferences increase they may wish to consume more, acquiring (some of) the necessary funds by increasing the supply of FAs.

In either of these cases, whether it is the desire of entrepreneurs to borrow more to finance new projects or the desire of consumers to borrow more to finance the purchase of consumers' goods, combined with the willingness of lenders to buy the new FA out of voluntarily supplied credit, there would be no systematic misallocation of resources as all decisions would be based on the freely undertaken actions of individuals.

In contradistinction, consider the situation if the increased supply of FA is the result of an increased willingness of the lenders to take on more risk. This case has to be subdivided according to the cause of the lenders' changed preferences. On the one hand, it might not involve governmental intervention, whereas on the other, it might. An example of the former would be if in a society characterized by increasing wealth, people decided to save more. In that case, they might prefer to make riskier, but potentially more lucrative, financial investments; i.e., lenders as a group may become less risk averse. In that case, the increased risk is 
warranted because it is in keeping with individuals' preferences. ${ }^{35}$ Thus, the resource reallocations resulting from the use of the additional credit are not misallocations - at least, not systematic misallocations. An example of the latter might occur if the central bank purchased FA with newly created funds in the form of reserves, creating excess reserves. In that case, the banks might prefer to take on more risk in their lending in order to maintain nominal rates of interest rather than being forced to accept lower rates of interest on their loans in order avoid greater risks. However, in this situation, the increased risk is not warranted because it results from fiat money/credit inflation. And, the resource reallocations consequent on this credit inflation are systematic misallocations. ${ }^{36}$

35 Since the genesis of this change is exogenous, we have no particular reason to believe it will change. That is to say, as long as this taste remains constant, economic decision-making based upon it can be sustainable. This is in sharp contrast to the Fed artificially lowering interest rates, setting up the classic ABC. Consider now the rare case where the Fed's actions are exactly consonant with changing time preferences; will the ABC take place even under these circumstances? We answer as follows: Even if peoples' time preferences were decreasing at the same time the Fed was monetizing debt and artificially lowering interest rates, there would still be an $\mathrm{ABC}$ problem; to wit: people save more so interest rates go down, but at the same time the Fed increases money/credit causing interest rates to fall even more; i.e., excessively. Plus the Cantillon (1959) effects re the new money/interventionist-credit. As Cantillon (1959) explained, money is non-neutral; i.e., it has injection/distribution effects. Suppose one were to maintain that because the borrowers of the new saving spend the money in different ways than would have been the case for providers of the new saving; had the latter's time preferences not decreased, such increased saving would initiate Cantillon-like effects. Still, the effects would indubitably be quite different, both in direction and, especially, in quantity than those that would come about when the Fed purchases immense amounts of securities, usually U.S. Treasuries, but in recent years, also a lot of Mortgage Backed Securities, from a very, very small number of sellers.

36 We speculate that one way to distinguish the former from the latter may be to consider the difference between brokered transactions and dealer transactions (Among other ways of characterizing financial intermediaries, we may classify them as either brokers or dealers. (Of course, many firms act in both capacities; nevertheless these are quite different functions.) In a brokered transaction, the broker is not a principal; rather, he is an agent. That is, the broker neither buys nor sells FAs, but rather brings together the buyer and seller for a fee or commission. A dealer, on the other hand, is a principal. He buys and sells FAs on his own account, sometimes for «proprietary» purposes and sometimes to «make a market» for a customer. (It should be noted that it can be very difficult to distinguish/determine the purpose of a 
There is yet another possibility. There is credit inflation without a fiat money inflation when the amount of maturity mismatching involving non-demand liabilities increases. ${ }^{37}$ In those cases the issue arises whether this causes systematic misallocations of resources. We are on record elsewhere, and continue to hold the views expressed there, that maturity mismatching (of the borrow short-lend long variety) is, on the one hand, unethical (Barnett and Block, 2009A), and on the other hand, capable of generating a business cycle of the Austrian type, provided, of course, that the magnitudes involved are sufficiently large (Barnett and Block, 2009B). We consider maturity mismatching here not merely because it is a central feature of modern economies, but because it plays a, if not the, critical role in unwarranted credit expansions, inflations and subsequent collapses of asset prices, liquidity crises, and insolvencies.

dealer's transactions. This fact is currently causing tremendous problems for governmental regulators trying to write regulations to enforce the so-called Volcker Rule - a part of the «Dodd-Frank Law» that is intended to prohibit banks and other financial institutions that own banks from engaging in proprietary trading for their benefit at the expense of their banking customers. Of course, if one cannot draw a clear boundary between proprietary trading and market-making for customers, and if the former can be the cause of large penalties, then there will be a reduction in liquidity in markets with attendant increased costs.) Furthermore, banks, de facto, act as dealers when they sell FAs in the form of deposits of various types and bonds to their depositors and other creditors and then use the funds generated thereby to invest either by making loans or by buying FAs in the market. Thus a dealer is a principal in both transactions. In the former case, as lenders take on more risk by buying riskier securities directly from borrowers (and analogously in secondary markets), we would expect to see yields increase relative to what they otherwise would have been. However, there would be no reason to expect that brokerage fees per dollar value of transactions (in some ways analogous to net interest margin) would increase. In the latter case, however, as nominal yields on the FAs dealers purchase would tend to decline in line with those on the FAs they buy, they may (and, we think, have) attempted to increase their net interest margins by maintaining nominal yields via taking on more risk. Note well: Although commercial banking is not usually considered «dealing,» it is, de facto.)

37 Maturity mismatching cannot arise in brokered transactions; it can only be created in dealer transactions, though it is not necessary that such transactions involve maturity mismatching. Herein, we assume that maturity mismatching is of the borrow short-lend long type, although it can involve borrowing long-lending short. Obviously, fractional-reserve-demand-deposit banking involves maturity mismatching, and is understood as cause of the Austrian Business Cycle. 
VII

\section{A COMPARISON}

The standard Austrian, exposition of growth, e.g., by Garrison (2001, 57-67), compares saving-induced growth with a creditinduced boom, using a LF graph. In both cases there is an increase in the supply of loanable funds $\left(\mathrm{S}_{\mathrm{LF}}\right)$; i.e., the $\mathrm{S}_{\mathrm{LF}}$ curve shifts out to the right, lowering the rate of interest (i). The lower $i$ then induces an increase in the quantity demanded of loanable funds $\left(D_{L F}\right)$; i.e., a movement downward along the $D_{L F}$ curve. However, in the former case the shift in the $S_{\mathrm{LF}}$ curve is a result of an increase in saving consequent on decreased time preferences by individuals. In the latter case the shift in the $S_{L F}$ curve is a result of an increase in fiat money that enters the economy as a result of being lent into existence by the fractional-reserve, banking system.

Let us consider a different model in which we compare the latter (credit-induced boom) case not with saving-induced growth, but rather with investment-induced growth. That is, in the new model it is not the $S_{\mathrm{LF}}$ curve that shifts outward as a result of an increase in saving consequent on individuals' lowered time preferences; rather, the $\mathrm{D}_{\mathrm{LF}}$ curve shifts to the right due to an increase in investment consequent on increased profit expectations. In this new model, a rise in profit expectations causes entrepreneurs to increase investment, but in order to acquire the necessary resources they boost their $\mathrm{D}_{\mathrm{LF}}$; i.e., the $\mathrm{D}_{\mathrm{LF}}$ curve shifts outward, raising $i$. The greater i induces an increase in saving that manifests itself as an rise in the quantity supplied of loanable funds; i.e., a movement upward along the $\mathrm{S}_{\mathrm{LF}}$ curve.

Barnett and Block (2007) makes the point that in real terms saving and investment ${ }^{38}$ consist in one and the same set of acts

38 Many problems in economics arise from the unscientific use of language, especially ambiguity. A case in point that is relevant, here, has to do with the terms «saving» and «investment.» These terms are used to refer both to «real saving» and «real investment» and to «financial saving» and «financial investment.» Whereas real saving and real investing consist solely in the act of producing new capital goods (or, if we include Rothbard's (2004) «plain saving,» new durable consumers' goods), financial saving and financial investment are different matters. Thus, financial 
of production; to wit: the production of a new capital good. ${ }^{39}$ That is, in real terms investment and saving are identical; both consist of producing new capital goods (ignoring the production of durable consumers' goods that Rothbard $(2004,69)$ refers to as "plain» saving), and it is the entrepreneurs who make the decisions regarding production; i.e., the allocation of resources to the production of various goods, including real investment. In that sense, it is real investment/saving that causes growth and it seems meaningless to say that growth is caused by saving or by investment. Because saving is investment and vice versa, it is meaningless to say that growth is caused by saving or by investment.

\section{VIII \\ CONCLUSION}

Austrian economics is well known for its $\mathrm{ABCT}$, and, also, for its emphasis on risk. However, these two concepts have not been brought together in the literature sufficiently, in our estimation. In this paper we have attempted to rectify this oversight by incorporating the former into the latter. Austrian growth theory is also well known for its emphasis on falling time preferences as an impetus. We expand on classical Austrian macroeconomics by considering the impetus for growth, also, on the supply side, or on the part of entrepreneurs who see greater profit opportunities than before.

\footnotetext{
investment consists, virtually always, in the exchange of the capital-good money (Barnett and Block, 2005) for title to some other capital good; e.g., the purchase for money of: bonds; shares of stocks; certificates of deposit; and, titles to commercial real estate. However, such transactions are not usually considered financial saving. Rather, financial saving consists in the exchange of the capital-good money for deposits at a depository institution; e.g., the exchange of money for: transactions deposits; savings deposits, including Money Market Deposit Accounts; time deposits, including CDs; and Money Market Mutual Funds.

39 We are speaking here of what Mises $(1998,527)$ classifies as «capitalist saving» in contradistinction to that which he classifies as "plain saving.»
} 


\section{APPENDIX: \\ ECONOMIC ANALYSIS OF «THE» MARKET FOR LOANABLE FUNDS.}

In figure 8 , consider the area $\mathrm{i}_{0} \bullet \mathrm{LF}_{0}$. It represents the total interest to be paid for the amount of loanable funds, $\mathrm{LF}_{0}$ if those funds are borrowed at a rate of $i_{0}$. Therefore, if a change in the $\mathrm{S}_{\mathrm{LF}}$ would induce an increase in the «quantity-demanded» of LF that would move the market clearing point on the $\mathrm{D}_{\mathrm{LF}}$ into its inelastic range, the total interest income would decrease. That alone, one might think, would be sufficient cause for the lenders (banks) to consider increasing the risk profile of its borrowers in the hope of maintaining interest revenue. ${ }^{40}$

FIGURE 8

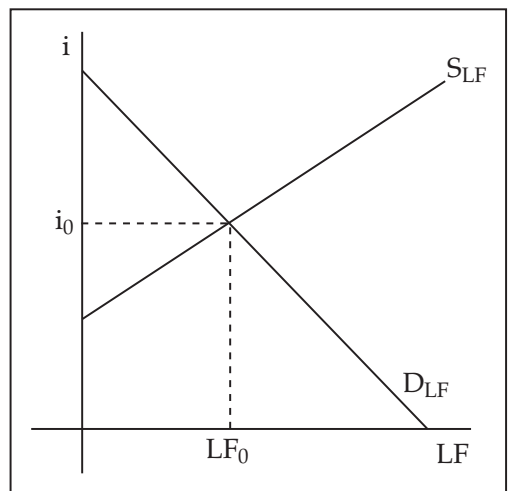

Example. Let $\mathrm{D}_{\mathrm{LF}}$ be given by: $\mathrm{i} / \mathrm{yr}=0.50 / \mathrm{yr}-(0.0005 / \mathrm{yr} \bullet \$) \mathrm{LF}(\$)$, alternatively $\mathrm{D}_{\mathrm{LF}}^{\prime}$ : $\mathrm{LF}(\$)=\$ 1,000-\$ 2,000 \mathrm{i} .{ }^{41}$ This illustrated in Figure 9. The total amount of interest payments, I, expected to be received by the lender(s) is: $\mathrm{I}(\$ / \mathrm{yr})=\mathrm{i} / \mathrm{yr} \bullet \mathrm{LF}(\$)$. If we

40 According to the old economic aphorism, «if they coulda, they woulda.» That is, why did not the banks already do this before the change we posit in the text? The answer is, We assume the lending institutions were already assuming what they saw as the optimal amount of risk. Moreover, they would not yet be in the inelastic region, thus the marginal interest would still be positive.

${ }^{41}$ Because there is no term for loans associated with the LF model, to simplify matters we assume that the term of loans is one year and the interest rate is per annum. 
FIGURE 9

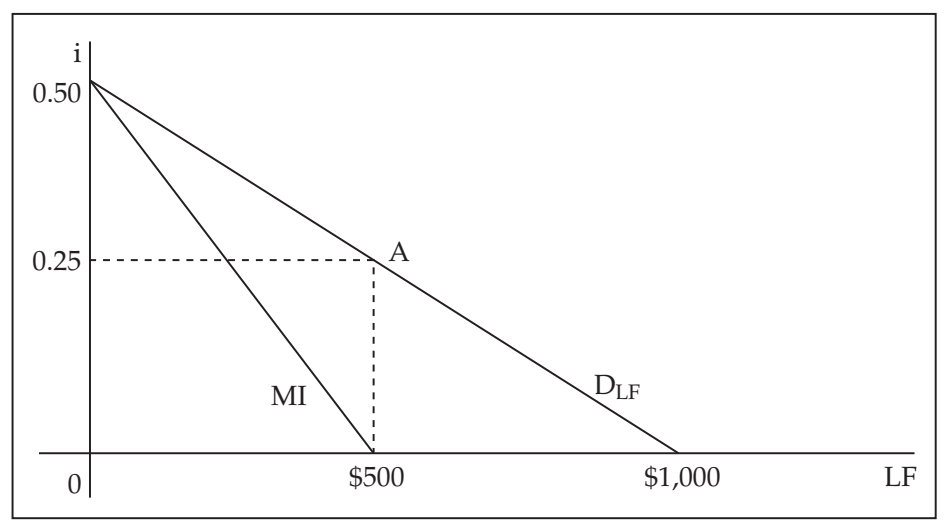

define marginal interest (MI) as $d \mathrm{I} / d \mathrm{LF}$, then $d \mathrm{I} / d \mathrm{LF}=\mathrm{i} / \mathrm{yr}$, and I is maximized at $d \mathrm{I} / d \mathrm{LF}=0$; i.e., at $\mathrm{LF}=\$ 500$, which corresponds to $\mathrm{i} / \mathrm{yr}=0.25 / \mathrm{yr}$. Thus, given borrowers' demands for loanable funds, at any $\mathrm{i}<0.25 / \mathrm{yr}$, lenders would have to lend more funds for less total interest in order to entice borrowers to borrow.

Consider, instead, the following. Assume FAs are notes $(\mathrm{N})$, sold at discount, each $\mathrm{N}$ with principal value $\$ 1$ and one year maturity. Then, if $\mathrm{P}_{\mathrm{N}}(\$ / N)$ is the price of $\mathrm{N}$, then $\mathrm{P}_{\mathrm{N}}(\$ / N) \bullet$ $(1 /((1+\mathrm{i}) / \mathrm{yr})) \bullet \mathrm{yr}=\$ 1 / \mathrm{N}$; i.e., $\mathrm{P}_{\mathrm{N}}(\$ / N)=\$ 1 / \mathrm{N} /(1+\mathrm{i})$. If the quantity of $\mathrm{N}$ is $\mathrm{Q}_{\mathrm{N}}$, then $\mathrm{P}_{\mathrm{N}} \bullet \mathrm{Q}_{\mathrm{N}}=\mathrm{LF}$, the $\mathrm{S}_{\mathrm{FA}}$ is given by: $\mathrm{Q}_{\mathrm{N}}=$ $3,000 \mathrm{~N} / \mathrm{P}_{\mathrm{N}}-2,000 \mathrm{~N} /\left(\mathrm{P}_{\mathrm{N}}\right) .^{2}$ Figure 10 illustrates the $\mathrm{S}_{\mathrm{FA}}$.

Chart 1 shows the relations among i, LF, $\mathrm{P}_{\mathrm{N}}, \mathrm{Q}_{\mathrm{N}}, \mathrm{P}_{\mathrm{N}} \bullet \mathrm{Q}_{\mathrm{N}}$, and I. Note that at the interest maximizing point $\mathrm{A}(\mathrm{i}=0.25, \mathrm{LF}=$ $\$ 500)$ in figure 9 and $A^{\prime}\left(P_{N}=\$ 0.80, Q_{N}=625 N\right)$ in figure $10, I=$ $\$ 125$. This can be interpreted in terms of LF, as borrowers' demand at an interest rate of 25 percent per annum was for $\$ 500$ with a promised interest payment of $\$ 125$. Alternatively, borrowers sold $625 \$ 1$-face-value, one-year notes at a $20 \%$ discount; i.e., for $\$ 0.80$ each or $\$ 500$ in total, promising to buy them back for $\$ 1$ each, or $\$ 625$ in total. Therefore total interest $=\$ 125$.

Note that, given borrowers' supplies of notes, at any price greater than $\$ 0.80$ per note, lenders would have to pay more for the notes for a smaller total discount; i.e., for less interest, in order to entice borrowers to sell. 
FIGURE 10

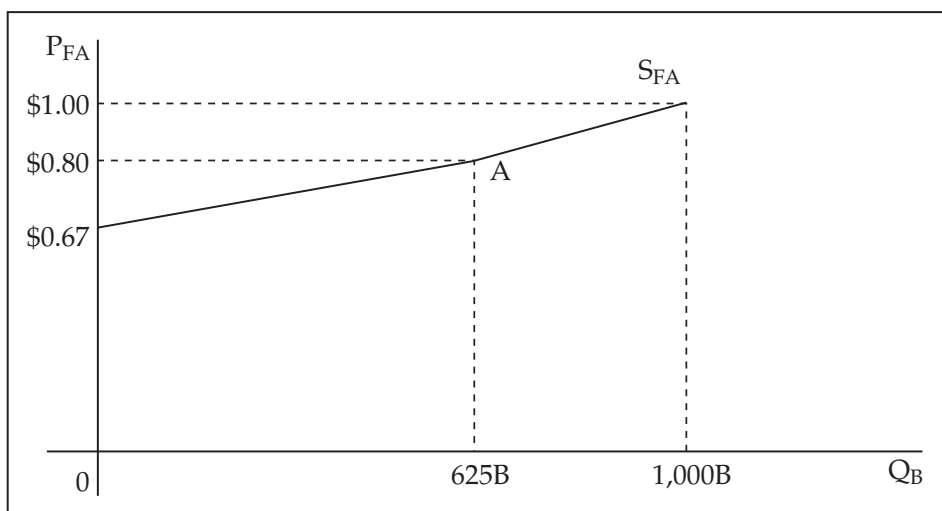

CHART 1

\begin{tabular}{|c|c|c|c|c|c|}
\hline i & $\mathrm{LF}$ & $P_{N}$ & $\mathrm{Q}_{\mathrm{N}}$ & $\mathrm{P}_{\mathrm{N}} \bullet \mathrm{Q}_{\mathrm{N}}$ & I \\
\hline 0.50 & $\$ 0$ & $\$ 0.67$ & $0 \mathrm{~N}$ & $\$ 0$ & $\$ 0$ \\
\hline 0.40 & $\$ 200$ & $\$ 0.71$ & $280 \mathrm{~N}$ & $\$ 200$ & $\$ 80$ \\
\hline 0.33 & $\$ 333$ & $\$ 0.75$ & $444 \mathrm{~N}$ & $\$ 333$ & $\$ 111$ \\
\hline 0.30 & $\$ 400$ & $\$ 0.77$ & $523 \mathrm{~N}$ & $\$ 400$ & $\$ 123$ \\
\hline 0.25 & $\$ 500$ & $\$ 0.80$ & $625 \mathrm{~N}$ & $\$ 500$ & $\$ 125$ \\
\hline 0.20 & $\$ 600$ & $\$ 0.83$ & $720 \mathrm{~N}$ & $\$ 600$ & $\$ 120$ \\
\hline 0.10 & $\$ 800$ & $\$ 0.91$ & $880 \mathrm{~N}$ & $\$ 800$ & $\$ 80$ \\
\hline 0.00 & $\$ 1,000$ & $\$ 1.00$ & $1,000 \mathrm{~N}$ & $\$, 1000$ & $\$ 0$ \\
\hline
\end{tabular}

\section{BIBLIOGRAPHICAL REFERENCES}

BARNETT, W. II and Block, W.E. (2005): «Money: Capital Good, Consumers' Good, or (Media of) Exchange Good?» Review of Austrian Economics. 18 (2): 179-194; http:/ / www.gmu.edu/ rae/archives/VOL18_2_2005/4_Barnett.pdf

- (2007): «Saving and Investment: A Praxeological Approach.» New Perspectives on Political Economy, Vol. 3, N.․ 2, pp. 129138; http://pcpe.libinst.cz/nppe/3_2/nppe3_2_1.pdf; 
http://141.164.133.3/exchange/walterblock/Inbox/Re\%20 query.EML/nppe3_2_block.pdf/C58EA28C-18C0-4a979AF2-036E93DDAFB3/nppe3_2_block.pdf?attach=1

- (2009a): «Time deposits, dimensions and fraud,» Journal of Business Ethics; Vol. 88, N. 4, September, pp. 711-716;

- (2009b): «Financial Intermediaries, the Intertemporal-Carry Trade, and Austrian Business Cycles; or; Crash and Carry: Can Fraudulent Time deposits lead to an Austrian Business Cycle? Yes.» Journal Etica e Politica / Ethics \& Politics; Vol. XI, N.o 1, pp. 455-469; http://www2.units.it/ etica/2009_1/ BARNETT_BLOCK.pdf

- (2010): «Mises never used demand curves; was he wrong? Ignorant? No: The Antimathematicality of Demand Curves.» Dialogue, Vol. 1, pp. 23-31, March; http:/ / www.unisvishtov.bg/dialog/2010/1.10.WB.pdf

- (2011): Forthcoming. "Loanable Funds, Saving and Investment, and Financial Assets.» Romanian Economic and Business Review.

CANTILlON, R. ([1730]1959): Essai sur la Nature du Commerce in Général (Essay on the Nature of Commerce in General). London: Frank Cass and Co., Ltd. http:/ /www.econlib.org/ library/NPDBooks/Cantillon/cntNT.html

Garrison, R.W. (2001): Time and Money. Routledge.

HAYEK, F.A. (1972): A Tiger by the Tail, London: Institute of Economic Affairs.

Keynes, J.M. ([1936] 1964): The General Theory of Employment, Interest, and Money. New York: Harcourt, Brace and World

Leibenstein, H. (1966): «Allocative Efficiency vs. X-Efficincy.» American Economic Review. 56(3): 392-415.

Mises, L. von (1998): Human Action. Scholar's ed. Ludwig von Mises Institute.

Rothbard, M.N. (2004 [1962]): Man, Economy and State, Auburn AL: Ludwig von Mises Institute, Scholar's Edition; http:/ / www.mises.org/rothbard/mes.asp

SCHUMPETER, J.A. ([1934] 1974): The Theory of Economic Development. Oxford: Oxford University Press. 